Marko Malović1, Miloš Roganović ${ }^{\star}$, Mustafa Özer ${ }^{3}$

${ }^{1}$ Educons University, Novi Sad, Serbia

${ }^{2}$ Faculty of Business, Economics and Entrepreneurship, Belgrade, Serbia

${ }^{3}$ Anadolu University, Eskişehir, Turkey

\title{
Pricked by the Virus for good? Real Estate Bubbles and the Grand European Shutdown
}

DOI: 10.7595/management.fon.2021.0023

Abstract:

Research Question: The objective of this particular piece of research was to evaluate the condition of the real estate market in the period preceding the pandemic outbreak. Motivation: Our goal was to determine whether real estate has been overpriced, i.e., whether and when speculative bubbles began to form and whether there were indications of their bursting. This paper brings together the need for discussing theories that can potentially explain the real estate market bubbles and boom-bust cycles (Gleaser \&Nathanson, 2014) and the new approach which proved promising to detect the exuberance of economic and financial activities (Phillips, Shi \&Yu, 2015). Potential collapse of real estate prices would have devastating effects and would likely cause a collapse of the financial system. Idea: The core idea of this paper was to evaluate whether speculative bubbles could be detected in the real estate market over the period immediately before the outbreak of the COVID-19 virus pandemic, and whether the pandemic or the financial crisis arising from it led to bursting of bubbles in this market and consequently brought their economies into even deeper crises. Data: Quarterly price movements were analyzed in the real estate market in six countries: Italy, Spain, the United Kingdom, Serbia, Croatia and Slovenia in the period Q1 1980 - Q4 2019 for Italy, Spain and the United Kingdom; Q1 2002 - Q4 2019 for Serbia and Croatia and Q1 2007 - Q4 2019 for Slovenia. Tools: Empirical analysis has been performed by utilizing generalized subaugmented Dickey-Fuller (GSADF) test of unit roots for the detection and data stamping of bubbles in the real estate market in time series at hand. Findings: In conclusion, grand European shutdown and COVID pandemic apparently did not prick multiplicity of previously formed real estate bubbles, at least not for the time being. Moreover, in several developing countries with stunted financial markets, the virus may have somewhat paradoxically solidified real estate prices and even sustained a build-up of rational real estate bubbles. Contribution: This paper expands previous research on real estate bubbles and provides new insights into the initial consequences of the COVID-19 pandemic.

Keywords: Real Estate Bubbles, Grand European Shutdown, GSADF Test, Boom-Bust Cycles, COVID-19

JEL: F30, F65, C58, R31

\section{Introduction}

The global economy has been pushed into recession due to the Covid-19 virus pandemic that has locked down millions of people around the world in their homes, causing humongous supply-shocks, job losses and inability or unwillingness to spend. Economic activity has slowed significantly, aggregate demand in turn contracted even more, we've experienced a dreadful stock market crash and unprecedented fall in the crude oil price, while international trade has been almost entirely halted. Clearly, the toll of the ensuing health and financial crisis threatens to become at the very least comparable to the Great Depression of 1929. At the time of this writing, the crisis is rapidly spreading across countries and remaining market segments alike.

The objective of this particular piece of research is to evaluate the condition of the real estate market in the period preceding the pandemic outbreak in six selected developed and developing economies and to determine whether real estate has been overpriced, i.e., whether and when speculative bubbles began to form and whether there were indications of their bursting. For the purpose of testing time series, the following hypotheses are set: Null hypothesis - time series has a unit root; and alternative hypothesis - multiple recurrent asset bubbles. The non-acceptance of the null hypothesis in these tests indicates the existence of bubble episodes. 
Specifically, authors are interested in whether financial crises in general and COVID-19 pandemic in particular may be a needle that has punctured a bubble and brought the world economy into crisis. Moreover, and in contrast to developed countries, the paper questions whether real estate bubbles per se on balance represent a positive or a negative phenomenon in developing countries during an international financial crisis.

The rest of the article is organized as follows: in section 2, a brief literature review on the real estate bubbles and initial impact of pandemic on this market segment is provided, in section 3 the authors present the sample and the methodology used as well as perform the empirical estimation, section 4 contains results and discussion, while in section 5 the paper is brought to a conclusion.

\section{Literature Review}

Real estate is a form of real property that involves construction land along with any improvements built or installed, including the right to possess, sell, lease and extract. There are five main types of real estate recognised in the literature: 1) Residential (housing), 2) Retail (commercial), 3) Industrial (factories, plants, silos etc.) 4) Land (undeveloped property, vacant land etc.) and 5) Special purpose (hospitality sector, graveyards, parks, places of worship etc.) (Nuredini, 2020).

Sure enough, the real estate market is confronted with great uncertainty due to COVID-19. The Covid-19 virus pandemic has significantly reduced consumption, increased unemployment and reduced workers' incomes. This should arguably have a significant influence on the capability of individuals to pay rent, mortgage debt and miscellaneous household expenses. Many are worried that we will face another financial crisis, similar to if not harder from the one in 2008 (Nicola, Alsafi, Sohrabi, Kerwan, Al-Jabir, losifidis, Agha \&Agha, 2020).

Cheshire and Hilber (2020), in analysing the UK housing market, maintain that real house prices and rents may well fall in the short- to medium-term, but lower real estate affordability is also to be driven by the fall in earnings. Similar findings are reported under two distinct recovery scenarios for Ireland by Coghlan and McQuinn (2020) as well as for India by Mishra (2021).

Karpook, Stillebroer and Jaspers (2020), on the other hand, argue that industrial and commercial real estate prices might easily go up as a result of the grand shutdown, due to the new imperative for construction workers to erect resilient buildings in view of defence against current and future contamination risks.

In the US and in the Russian Federation, for instance, real estate prices barely edged down for a notch, however, the most visible impact of this lockdown on housing has been the collapse of sales transactions and prolonged time that realtors have kept the same ads running (Schnure, 2020), (Avakyan \&Pratsko, 2020). By the same token, Huang, Pang and Yang (2020) examined the behaviour of the housing market in China after the COVID-19 outburst and the subsequent economic reopening. They constructed weekly housing price indices for 64 cities by analyzing more than 700,000 housing transaction records in 2019 and 2020. Their empirical evidence indicates that the COVID-19 pandemic has had a small negative effect on housing prices but a substantial negative effect on transaction volume. Time on market is also found to lengthen (Ibidem). Hu, Lee and Zou (2021) followed daily housing price index for five cities in Australia and detected a negative relationship between the COVID-positive cases and housing returns, but insignificant outcome of lockdown intensity on real estate return.

Ghiaie (2020) develops a two-country model of a monetary union to evaluate the interaction between real estate, credit market and unconventional monetary policy aimed at easing the economic cost of the pandemic. The model features a housing accelerator and the post-crisis house price double-dip. His findings illustrate the pattern along which macro-housing channels lead to self-reinforcing loops, affecting the portfolio rebalancing channel as the principal way for asset purchases to tackle the rest of the economy. Due to those back-firing loops, unconventional monetary policy turns out to be a necessary but not sufficient ingredient for economic recovery; as a matter of fact the authors argue later in this paper that an underdeveloped financial sector might be somewhat destabilizing for the real estate market (sustainable) equilibria.

Liu and Su (2020) utilised detailed housing data to study the impact of the COVID-19 pandemic upon the location of the real estate demand. They maintain that the epidemic has led to a reduced demand for housing in districts with high population density. The reduced demand for density is governed in part by the diminished need of living close to jobs that are distance-compatible and the declining value of access to shopping areas. Neighborhoods with high pre-COVID-19 home prices also see a greater drop in housing demand. While the national housing market recovered after June, Liu and Su (2020) demonstrate that the adverse effect of COVID on the demand for density persevered in the post-shutdown period too. 
Carson, Nanda, Thanos, Valtonen and Xu (2020) along with Hoesli and Malle (2021) underscore divergent price behaviour of different forms of real estate which they expect to persist through the crisis - industrial and residential real estate price appear to be sticky, while office buildings, hospitality and retail properties might continue to take the beat pricewise. Carson et al.(2020) even fear that commercial real estate may retreat from the high street into online presence forever as a consequence of this giant shutdown.

Nowadays in most corners of the world it appears inconceivable that until recently real estate prices tended to double every couple of years. Speculative bubble episodes were commonplace indeed, hence it is interesting and important to verify their build-up ahead of pandemic and determine whether the grand European shutdown was meant to burst them across the board. The bubble creation episode typically refers to a situation where the price of an asset starts to rise rapidly for no obvious fundamentals-supported reason (El Montasser, Fry \&Apergis, 2016). Throughout history, financial crises and property bubbles have been linked directly and intimately with one another. For example, Irish house prices increased in nominal terms by $470 \%$ from 1995 to 2007, only to plummet 53\% from 2007 to 2012, wherefrom they yet again rose steadily before the next crisis hit (Coghlan \&McQuinn, 2020). The value of the property, it goes without saying, derives from the dividends it pays. The real estate market is hence directly linked to macroeconomic and financial stability. Economic ups and downs are closely related to real estate price fluctuations, primarily due to the size of this market segment. The experience of the global recession of 2007 warns us that the devastating effect of bursting of the real estate bubble leaves more intense consequences compared to the collapse of other given asset.

Housing markets tend to experience substantial price volatility, short term price change momentum and mean reversion of prices in the long run (Gleaser \&Nathanson, 2014). In other words, they make up a rather fruitful soil for asset bubble formation. Housing demand, following Liu, Liu, Malekian, Li and Wang (2017), may be determined by a vector of fundamentals such as real estate price, nominal income, population density, mortgage rate of interest, existence of a credit boom and the like.

$$
\begin{gathered}
h^{d}=f\left(p^{R E}, Y, \delta^{N}, i^{M}, c^{b o o m}, \ldots\right) \\
(-),(+),(+),(-),(+)
\end{gathered}
$$

Accordingly, the logarithm of real estate price could be defined as an array of logarithmic explanatory variables and an econometric residual, which is itself a difference between the actual and an estimated real estate price, or in other words, the sum of rational price fluctuation including random disturbance on one hand and an abnormal either bubbly or underpricing process:

$$
u_{j t}=\log p^{R E}-\log p^{\wedge R E}=e_{j t^{-R E}}{ }_{j t}
$$

In equation (2), $j$ denotes country whereas $t$ is time operator. Naturally, higher real estate prices to the extent discourage non-speculative buyers, bigger income strengthens effective demand for living space, population density increases demand and raises the prices of real estate, whereas lower interest rates on mortgage loans stimulate demand and consequently pull up the price of apartments.

Nonetheless, Jorda, Schularick and Taylor (2015), who studied housing bubbles in 17 countries over 140 years, warn about the fact that however similar they may appear, not all real estate bubbles are the same. Some of them cause nasty boom-bust cycles and shake the entire economies while others simply blow over and exhaust. Actually, systematically lowered interest rates and loosened credit conditions for a while create particularly sinister circumstances conducive with regards to real estate bubble formation. Similar takeaways are offered by Gleaser and Nathanson $(2014$, p.1) in that " $(. .$.$) cheap credit provides a particularly common$ rationalization for housing price booms", as well as by Cerutti, Dagher and Dell'Ariccia (2017, p.1) later on, who claim that "(...) house-price booms seem to be more likely in countries with higher loan-to-value ratios".

In addition, Caballero and Krishnamurty (2006) have showed that - in developing countries with emerging financial markets - bubbles may turn out to be beneficial after all because they offer otherwise scarce domestic stores of value and as such reduce capital outflows whilst promoting inbound investment. But they come at a price, as they potentially expose these countries to bubble bursts and intense capital flow reversals. Besides, Glaeser (2017) asserts that real estate is an obvious investment destination for more risk-averse investors, including banks, especially in shallow securities markets fraught with agency problems. Thus, passive capital flows disproportionately into real estate of emerging markets so that errors of passive capital often generate real estate bubbles. To top it all off, Caballero and Krishnamurty (2006) further display that domestic financial underdevelopment not only expedites the occurrence of bubbles, but also leads agents to underestimate the aggregate risk embodied in real estate bubbles in as much as even rational bubbles can be welfare-reducing. This, however, makes all the more important to find the reliable methodology for timely detection of real estate bubbles. 


\section{Methodology and Empirical Estimation}

Speculative bubbles can be defined as an asset that is traded at a price that is substantially higher than its fundamental value (Barlevy, 2018). Therefore, if prices do not perfectly reflect yields, price deviations can only be explained as speculations (Kholodilin \&Michelsen, 2018). The existence of speculative bubbles is by now pretty much unquestionable, and throughout history there were numerous examples of the creation and bursting of speculative bubbles, which inevitably led to long-term crises with terrible consequences. The challenge is to try to detect speculative bubbles in a timely manner and minimize their undesirable effects.

Theoretically, a logical test of existence of rational real estate bubbles would be to verify whether request to payments at infinite maturity have zero net present value, which is empirically almost impossible to conduct (Gigglio, Maggiori \&Stroebel, 2014). Early attempts to detect speculative bubble episodes relied on ex-post tests and could not confirm the existence of bubbles with certainty. Moreover, indirect tests that researchers have instead turned to are inevitably model-dependent, since they suffer from the so-called joint hypothesis problem: imperative to simultaneously confirm the presence of a bubble and validity of the econometric model deployed (Ibidem). In addition, Evans (1991) warned of joint hypothesis-related pitfalls in previous attempts to prove the existence of asset price bubbles. After analyzing and criticizing numerous previous studies and methodologies developed during the 1980s, Evans concludes that several groups of tests constructed and championed until the early 1990s are in fact unsuitable for detecting rational bubbles. Further, he argues that - by using classical tests to determine whether stock \& real estate prices are more explosive or less stationary than dividends \& returns yielded - it is possible to overlook periodically collapsing bubbles. Campbell and Shiller (1987) also conclude that there is insufficient evidence of eruptive behaviour when performing standard testing procedures.

While seeking procedure that will provide an accurate explosive behaviour testing mechanism, i.e., data stamping the formation and collapse of speculative bubbles, including current confidence intervals for explosive growth rates, Phillips, Wu and Yu (2011) (hereinafter PWY) developed a method involving recursive right-tailed unit root test and sub-test suitable for practical application. The approach adopted in PWY uses the sub-augmented Dickey-Fuller (SADF) test based on the sequence of forward recursive right-tailed ADF unit root tests. This proceeding as well provides a data stamping strategy that identifies the points of onset and cessation of the bubble episode. When the observed period potentially contains multiple periods of explosive growth and collapse, the SADF test becomes inconsistent and fails to detect the existence of bubbles.

Homm and Breitung (2012), in a similar fashion, evaluated the existing explosive behavior tests in extensive simulations and concluded that Chow type unit root tests for the identification of breakpoints in the gradation between unit root and explosive behaviour are favorable ex-post analysis of the entire data sample, but that the recursive PWY test behaved well in the prompt perception of such gradation and is desirable in an anticipatory role as a monitoring system. They also corroborate that the PWY test is more powerful in detecting multiple bubble periods than the other tests they discussed.

The complexity of the nonlinear structure inherent in multiple bubble occurrences within the same sampling period makes econometric analysis of these phenomena particularly difficult. The use of recursive proceeding in detecting and dating asset bubbles observing a longer historical period represents a significant econometric challenge. To meet this challenge, Phillips et al. (2015), (hereinafter PSY) developed a new recursive method with flexible intervals that is more suitable for practical application in long historical time series. To overcome the weakness of the PWY model and deal with multiple periods of boom and collapse, PSY proposes an alternative approach called the generalized sub-ADF (GSADF) test. The method is the generalized version of the SADF test (PWY) and provides a consistent strategy for determining the date of onset and cessation of bubble episodes. Simulations show that the test significantly improves the detection power when there are multiple periods of bubbles. The GSADF test also relies on the recursive ADF test but uses flexible window widths in the implementation. Phillips et al. (2015) demonstrated through a Monte Carlo study that the PSY strategy secured better results than the PWY strategy in detecting the existence of multiple episodes of bubbles.

In their paper, Afsar and Dogan (2018) summarized the theoretical and empirical studies applied to bubble detection in the real estate market. The models found in the literature are: log-periodic power law (LPPL) bubble model; Fixed Effect Ordinary Least Squares (OLS); right-tailed unit root tests; Markov Regime Switching Model; Exploratory Spatial Data Analysis (ESDA), Generalized Moments Method (GMM); ordinary least squares (OLS) / Fully Modified OLS (FMOLS) / Dynamic OLS (DOLS), Kalman filter and autoregressive integrated moving average ARIMA. Of the offered alternatives, they favoured the right-tailed unit root test. 
The right-tailed unit root tests have proven promising to detect the exuberance of economic and financial activities, which is why the GSADF methodology was chosen. More precisely, authors performed tests for the detection and data stamping of bubbles in the real estate market by using Rtadf (right-tailed augmented Dickey-Fuller), a software add-in for the eViews programme implemented by Itamar Caspi (Caspi, 2017). The add-in makes it easy to run time series tests that help detect and data stamp the asset price bubbles. This add-in calculates a test statistic, simulates the corresponding critical values of a constrained sample and $p$ values using the Monte Carlo simulation method, assuming a Gaussian (normal) distribution, and provides a graphical representation marked with a date stamp.

Bearing in mind the previous methodological record along with the aim of our own study, quarterly price movements were analyzed for the real estate market in six countries: Italy, Spain, the United Kingdom, Serbia, Croatia and Slovenia in the period from the first quarter of 1980 (Q1 1980) to the fourth quarter of 2019 (Q4 2019) for Italy, Spain and the United Kingdom; Q1 2002 - Q4 2019 for Serbia and Croatia and Q1 2007 - Q4 2019 for Slovenia. When calculating the price index, 2015 was taken as the base year. The required data for the research were picked up from OECD (2020) and Bank for International Settlements (2020) databases. In order to investigate the impact of the pandemic on the real estate market in both developed and developing European countries and given that the real estate market in Serbia has recently become a topic of utmost interest, these 6 countries in particular were selected also on account that they all had been severely affected by COVID-19 at least in the initial phases of the pandemic outbreak. Moreover, due to the international trade and territorial cohesion, it is expected that the virus and economic effects of the crisis alike are to be transmitted between selected countries.

\section{Results and Discussion}

It has been shown that the devastating effect of the real estate market bubble bursting has stronger consequences compared to the collapse of some other asset class. The case of the global recession from 2007 testifies to that end. As Kansu (2011) asserts that "the bursting of bubbles in the stock market causes less damage than the collapse of the real estate market" (as cited in Asfar \& Dogan, 2018, p. 140). In case of bubbles in the real estate market, the balance sheets of banks are more affected, and it is more likely that the fall in real estate prices will be negatively reflected and transferred to other sectors of the economy through credit channels. The collapse of real estate prices will affect the collapse of the financial system, which will be reflected in the real sector (Asfar \&Dogan, 2018). Housing loans make up a large percentage of household loans and usually represent a great deal of financial market activities. Furthermore, a very important feature of the real estate market is that a mortgage on housing is the most common form of collateral when it comes to bank loans. Therefore, falling real estate prices can significantly jeopardize the stability of banks as it leads to a significant increase in outstanding loans.

The results of the tests that were conducted are shown in Table 1.

Table 1: GSADF test results

\begin{tabular}{|c|r|r|r|r|r|}
\hline \multirow{2}{*}{ Tested countries } & \multicolumn{2}{|c|}{ GSADF test } & \multicolumn{3}{c|}{ Test critical values**: } \\
\cline { 2 - 6 } & t-Statistic & \multicolumn{1}{|c|}{ Prob.* } & $\mathbf{9 9 \%}$ level & $\mathbf{9 5 \%}$ level & 90\% level \\
\hline Spain & 3.305896 & 0 & 2.120907 & 1.519524 & 1.285149 \\
\hline Italy & 3.045291 & 0 & 2.120907 & 1.519524 & 1.285149 \\
\hline United Kingdom & 2.953888 & 0 & 2.120907 & 1.519524 & 1.285149 \\
\hline Serbia & 2.42139 & 0 & 1.543787 & 1.12324 & 0.908251 \\
\hline Croatia & 1.116417 & 0.051 & 1.543787 & 1.12324 & 0.908251 \\
\hline Slovenia & 1.061167 & 0.041 & 1.452355 & 1.011685 & 0.785862 \\
\hline$*$ Right-tailed test & \multicolumn{7}{|c}{} \\
\hline$* *$ Critical values are based on the Monte Carlo simulation (run with EViews) \\
\hline
\end{tabular}

Source: Authors' calculations 
At $90 \%$ confidence interval the obtained values of t-statistics are higher than the critical values for all tested countries, hence solid evidence has been gathered against $\mathrm{H}_{0}$ and in favour of $\mathrm{H}_{A}$. In the observed period, there are multiple episodes of bubble forming as well as bursting. At $95 \%$ confidence interval the obtained values of t-statistics are higher than the critical values for all tested countries except Croatia. At 99\% confidence interval the obtained values of t-statistics are higher than the critical values for Spain, Italy, UK and Serbia but not for Croatia and Slovenia. The results are further presented graphically (Figure 1).
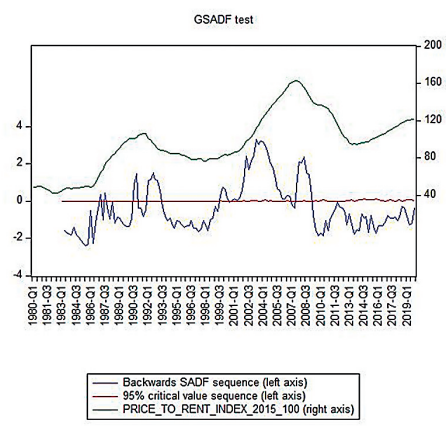

Spain
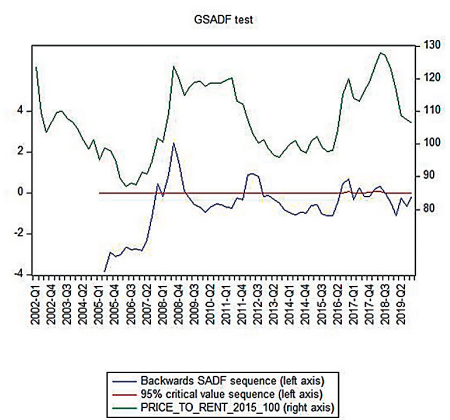

Serbia
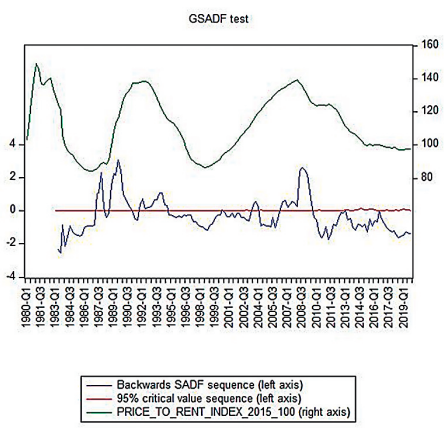

Italy

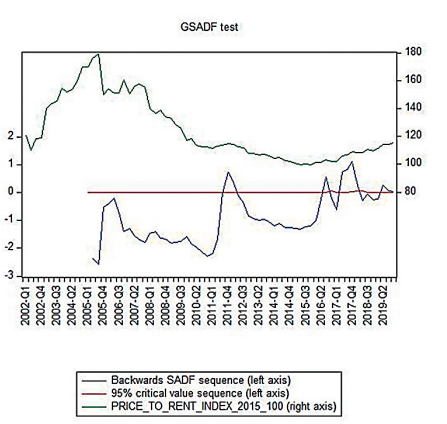

Croatia

Figure 1: GSADF test results
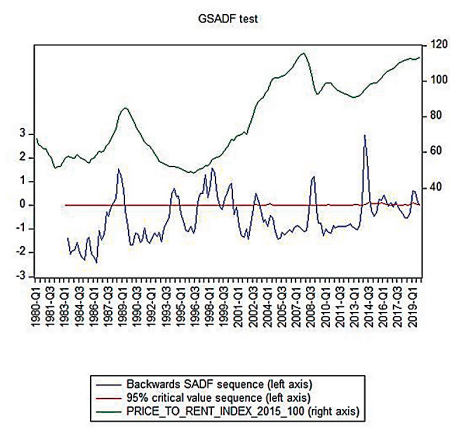

United Kingdom
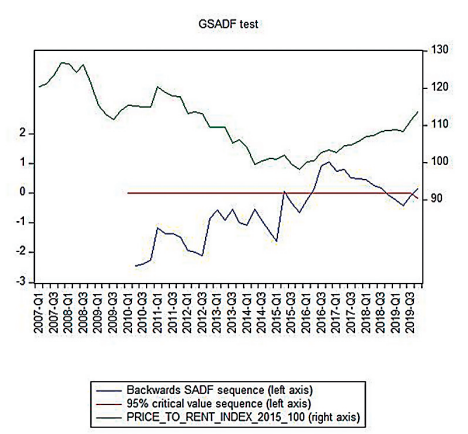

Slovenia

Source: Authors' calculations

Because PSY recommend one should ignore too short lasting bubble periods and identify only ones persisting more than $\log (\mathrm{T})$ units of time, those bubble periods - that persevere less than three quarters for Spain, Italy and UK and less than two quarters for Serbia, Croatia and Slovenia - will not be data stamped.

In Spain four periods of bubble episodes were detected: 1992Q1-1993Q2; 1999Q3-2000Q2; 2000Q42006Q4; 2007Q3-2009Q1. In Italy five periods: 1987Q2-1988Q1; 1988Q4-1990Q4; 1991Q4-1994Q3; 2003Q3-2004Q1; 2006Q2-2009Q3. In United Kingdom seven periods: 1988Q1-1989Q1; 1994Q1-1994Q4; 1996Q4-1998Q4; 1999Q3-2000Q2; 2013Q4-2014Q3; 2015Q3-2016Q2; 2019Q1-2019Q4. In Serbia four periods: 2008Q2-2009Q1; 2012Q1-2012Q3; 2016Q3-2016Q4; 2018Q1-2018Q2. In Croatia three periods: 2011Q4-2012Q1; 2017Q2-2018Q1; 2019Q2-2019Q4; and in Slovenia one episode of bubble booming and bursting, 2016Q2-2018Q3.

By examining the real estate market in the given countries, authors tried to answer the question of whether speculative bubbles could be detected in the real estate market over the period immediately before the outbreak of the COVID-19 virus pandemic, and whether the pandemic or the financial crisis arising from it led to bursting of bubbles in this market and consequently brought their economies into even deeper crises. After analyzing the nominal housing price index (depicted in Figure 2), it can be observed that in all countries, except Italy, there certainly was an extraordinary positive trend of price growth in the real estate market before the pandemic outbreak (Note: Authors were unable to deduce why ltaly appears to be an exception.). 


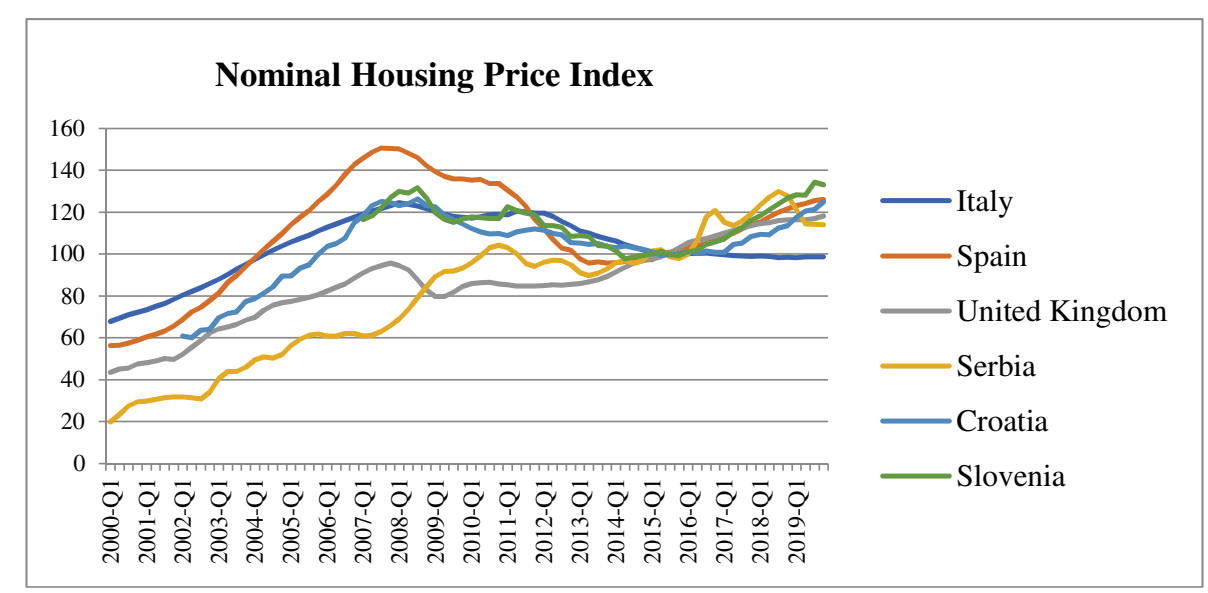

Figure 2: Nominal Housing Price Index

Source: Authors' plot based on data from OECD - Prices: Analytical house price indicators

In Croatia and Slovenia, the price level reached the sums which were recorded just before the outbreak of the economic crisis in 2007, while in United Kingdom and Serbia (Note: Following the fourth bubble period, after 2018Q2 until 2019Q4 authors failed to detect another bubble since renting got dearer $7.86 \%$ while prices of flats slightly fell in comparison with their peak in 2018Q3), new highs are being counted almost on a monthly basis. The aforementioned data give us the reason to assume that the real estate market in these countries might have been in a growing speculative bubble before the onset of the COVID-19 pandemic. However, to determine the presence of speculative bubbles in the real estate market, it is necessary to take into account the rental prices, respectively rental prices index, because rent is a decisive determinant of the return that brings investment in real estate.

In order to empirically confirm the presence of speculative bubbles, the GSADF test was conducted. Over the observed period, authors indeed detected multiple episodes of creating and bursting of bubbles in the real estate market in all tested countries. In the period around or just before the outbreak of the pandemic, excessive price growth in four countries was recorded: United Kingdom, Croatia, Slovenia and Serbia. Given the negative effects of the pandemic in the real sector, it was to be expected that the real estate market would subsequently suffer a sharp decline, especially in countries where abnormally inflated prices were detected even before the crisis took over. But there was no drop whatsoever. Interestingly enough, prices remain high with no signs of falling to this very day. An explanation for this phenomenon can be found in the stimulus measures of monetary and fiscal policy to combat the negative effects of the crisis resulting from the pandemic. Among other things, those have been lower interest rates, reduced participation in real estate purchase co-financed via loans, support packages for companies to preserve jobs, pumping money to maintain liquidity, helicopter money of sorts etc. In developing countries like Serbia, additional reasons can be found for the resilience or indeed rise in prices in the fact that securities markets are underdeveloped, to put it mildly, thus without variety of investment alternatives to choose from, surplus funds often times wind up effortlessly tucked in the real estate. Furthermore, in times of crisis, trust in banks typically dwindles, hence money gets withdrawn and ends up deposited in "safe havens", including real estate. Also, due to the more or less justified fear of inflation, investing in real estate seems to be a good option for preserving value. It comes to the paradox that the pandemic has actually triggered mechanisms that serve as fuel to sustain speculative bubbles in the real estate market. Be that as it may, one thing is certain - the more the bubble grows, the more severe its consequences will be when it eventually bursts. Another paradox is that bursting of bubbles in the real estate market can also have positive economic effects in developing countries, because the money pumped into this market might be redirected to other sectors or, to the very least, won't leave the country, thereby supporting the local growth.

More recently, Kholodilin and Michelsen (2018) voiced a concern that there might be another overvaluation in the real estate market on the horizon or that this is already a fact. What remains somewhat puzzling presently, i.e., during the pandemic, so far there has been no significant impact of the crisis on the real estate in several national market segments. Upon analyzing the real estate market in Campania Region in Italy, for example, in the country that is overall most affected by the virus, Del Giudice, De Paola and Del Guidice (2020) find no substantial impact on the real estate market so far, however, they trust it will not move independently of other economic variables in the longer run. According to the model they have developed, they expect housing prices to fall by $4.16 \%$ in the short term and by $6.49 \%$ in the medium term. 
After all, imminent overvaluation might be rationally induced by an interplay of market forces in several developing countries with underdeveloped stock exchanges. Due to the short-term rigidity of supply in the real estate market, lowering the interest rate leads to higher prices because the demand for real estate is increasing. The supply on the real estate market is quite rigid, mostly due to the lack (relative scarcity) of construction land and the time needed to complete construction. During the pandemic and lockdown, the real estate supply was further reduced or at least slowed down due to performing construction works in logistically cumbersome circumstances. Even in Serbia, where the construction industry's activity hasn't been halted by government's regulation, fewer construction permits have been issued in April and May. As can be seen in Figure 3, real estate prices are closely related to the interest rate. The constant lowering of interest rates keeps the real estate market overheated.

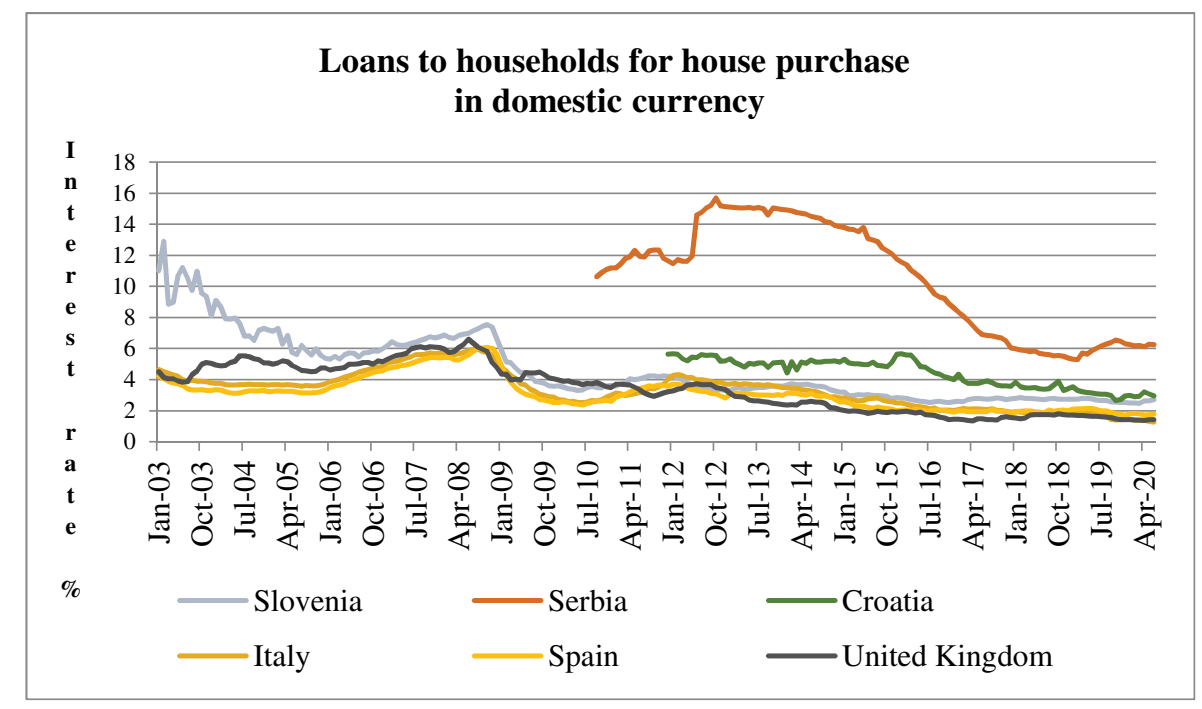

Figure 3: Loans to household for house purchase

Source: Authors' plot based on data obtained from central banks

One can also deduce from the data that the increase in interest rates immediately preceding the global recession (2006-2009) contributed to the bursting of bubbles in the real estate market, and their subsequent lowering stimulated the recovery of real estate prices. After analyzing the real estate market in Montenegro, Cetkovic, Rutesic and Knezevic (2011) found a similar correlation between lowering of interest rates and the consequent rise in real estate prices in this developing country. From the 2005Q1 until the 2008Q2, the mortgage rate was lowered by $42.9 \%$ which contributed to the increase in housing loans by as much as 36.7 times and consequently fed inflation of real estate prices by $88 \%$ in that period. As in Serbia, the first reaction to the onset of the global financial crisis was an increase in interest rates, which only accelerated the bursting of bubble in the real estate market and deepened the crisis in Montenegro as well.

Incentive packages for stimulating liquidity (Note: More about stimulative packages at https://www.imf.org/en/Topics/imf-and-covid19/Policy-Responses-to-COVID-19\#C) have also been contributing to maintaining high prices on the real estate market, because they create inflationary pressure, and part of the excess liquidity is directed to the real estate market as a safe harbor for preserving value. Indirectly, of course, monetary expansion of any kind tends to lower interest rates thereby slashing the interest rate burden of mortgage loans. Moreover, due to the fear of economic collapse, people withdraw money from banks and buy real estate for cash.

In addition, in less developed economies such as Serbia, where securities market is underdeveloped and average incomes are relatively low, remittances and external demand arguably may have had a huge impact on rising real estate prices. As a matter of fact, a large chunk of remittances end up being invested in real estate due to the intention of migrants to provide housing to their families left behind and as well as due to lack of other investment opportunities in the recipient developing economies (Maimbo \& Ratha, 2005). As can be seen in Figure 4, remittances make up over $8 \%$ of Serbia's GDP and over $6 \%$ of Croatia's GDP. 


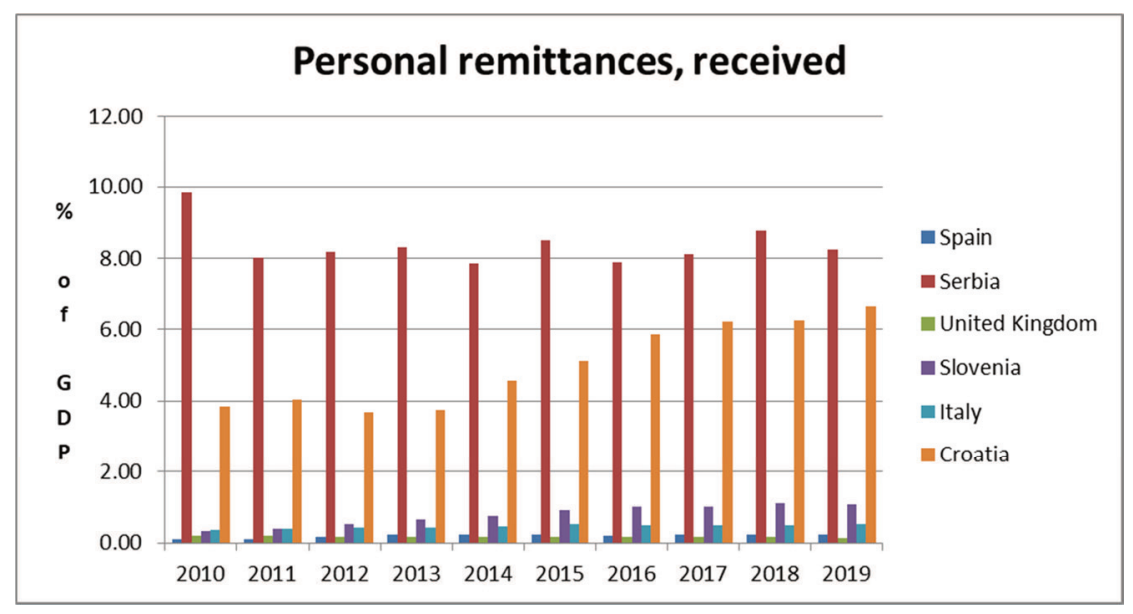

Figure 4: Inbound remittances

Source: Authors' plot based on data from World Bank database -WDI

This could at least to some extent explain the fact that large majority of flats and condominiums being sold in Serbia are paid for in cash. What is more, a larger proportion of new developments in real estate are smart buildings and smart flats that are dearer by default, while investors themselves endure ever fiercer competition in terms of steadily superior quality of materials being installed in new real estate, which jointly results in higher prices of apartments in metropolitan areas, faced with uninterrupted inflow of economically motivated migrants from the countryside.

\section{Conclusion}

In conclusion, the grand European shutdown and COVID pandemic apparently have not pricked a multiplicity of previously formed real estate bubbles, at least not for the time being. Moreover, in several developing countries with stunted financial markets, the virus may have somewhat paradoxically solidified real estate prices and even sustained build-up of rational real estate bubbles. Such a development obviously has its pros and cons which may differ quite strikingly in both substance and net prevalence over the short as opposed to the medium run.

Finally, like in any econometric exercise involving several countries whose sampled time-series stretch across overlapping periods, there may be a cross-sectional impact responsible for the part of observed variability in the real estate data. In order to check for and report on that eventuality, the authors performed a cross-sectional analysis available in the appendix. Even though our testing clearly suggests some cross-sectional dependence in dynamics of both price-to-rent and real-house-price indices, it is proverbially hard to offer a clear-cut theoretical explanation for reported results, which is why this is left at the moment as an avenue for future research.

\section{Appendix}

Cross-country exercises:

Table 2: Cross-Section Dependence Test 1

\begin{tabular}{|c|c|c|c|}
\hline $\begin{array}{l}\text { Cross-Section Dependence Tes } \\
\text { Series: PRICE_TO_RENT_INDE } \\
\text { Null hypothesis: No cross-sectic } \\
\text { Sample: 2007Q1 2019Q4 } \\
\text { Periods included: } 52 \\
\text { Cross-sections included: } 6 \\
\text { Total panel observations: } 312 \\
\text { Note: non-zero cross-section m } \\
\text { Cross-section means were remc }\end{array}$ & $\begin{array}{l}\text { ndence (co } \\
\text { tected in da } \\
\text { ring compu }\end{array}$ & on) & ons \\
\hline Test & Statistic & d.f. & Prob. \\
\hline Breusch-Pagan LM & 246.4221 & 15 & 0.0000 \\
\hline Pesaran scaled LM & 42.25170 & & 0.0000 \\
\hline Bias-corrected scaled LM & 42.19287 & & 0.0000 \\
\hline Pesaran CD & 11.38263 & & 0.0000 \\
\hline
\end{tabular}

Source: Authors' calculations 
Table 3: Cross-Section Dependence Test 2

\begin{tabular}{|c|c|c|c|}
\hline $\begin{array}{l}\text { Cross-Section Dependence Tes } \\
\text { Series: REAL_HOUSE_PRICES } \\
\text { Null hypothesis: No cross-sectic } \\
\text { Sample: 2007Q1 2019Q4 } \\
\text { Periods included: } 52 \\
\text { Cross-sections included: } 6 \\
\text { Total panel observations: } 312 \\
\text { Note: non-zero cross-section m } \\
\text { Cross-section means were remc }\end{array}$ & ndence (co & on) & ions \\
\hline Test & Statistic & d.f. & Prob. \\
\hline Breusch-Pagan LM & 293.1916 & 15 & 0.0000 \\
\hline Pesaran scaled LM & 50.79061 & & 0.0000 \\
\hline Bias-corrected scaled LM & 50.73179 & & 0.0000 \\
\hline Pesaran CD & 13.04132 & & 0.0000 \\
\hline
\end{tabular}

Source: Authors' calculations

\section{REFERENCES}

[1] Allen-Coghlan, M., \&McQuinn, K. M. (2020). The Potential Impact of Covid-19 on the Irish Housing Sector", , Vol. ahead-of-print No. ahead-of-print. , forthcoming

[2] Allen-Coghlan, M., \&McQuinn, K. M. (2020*). Property Prices and COVID-19 related Administrative Closures: What are the Implications?. ESRI Working Paper No. 661, mimeo.

[3] Afsar, A., \&Dogan, E. (2018). Analyzing Asset Bubbles in the Housing Market with Right-tailed Unit Root Tests: the case of Turkey. Journal of Business, Economics and Finance (JBEF), 7(2), 139-147.

[4] Avakyan, K. \&Pratsko, G. (2020). Impact of the Coronavirus Pandemic in 2020 on the Real Estate Market in Russia: Legal Aspects. E3S Web of Conferences 210, 13001. https://doi.org/10.1051/e3sconf/202021013001

[5] Barlevy, G. (2018). Bridging between Policymakers' and Economists' Views on Bubbles. Economic Perspectives, 4, 1-21.

[6] Caballero, R., \&Krishnamurthy, A. (2006). Bubbles and Capital Flows Volatility: Causes and Risk Management. Journal of Monetary Economics, 53(1), 35-53.

[7] Campbell, J., \&Shiller, R. (1987). Cointegration and Tests of Present Value Models. Journal of Political Economy, 95, 1062-88.

[8] Carson, S., Nanda, A., Thanos, S., Valtonen, E., \&Xu, Y. (2020), Viewpoint: Imagining a Post-COVID 19 World of Real Estate, Town Planning Review, Ahead of Print, pp.1-6; https://doi.org/10.3828/tpr.2020.63, Liverpool University Press, mimeo.

[9] Caspi, I. (2017). Rtadf: Testing for Bubbles with EViews. Journal of Statistical Software, 81, 1-16. Doi:

[10] Cerutti, E., Dagher, J., \&Dell'Ariccia, G. (2017). Housing Finance and Real-Estate Booms: A CrossCountry Perspective. Journal of Housing Economics, 38, 1-13.

[11] Cetkovic, J., Rutesic, S. \&Knezevic, M. (2011). Analysis of Existing Housing Fund and Current Housing Construction With Focus on Real Estate Market in Montenegro. Management (1820-0222), Vol. 16 Issue 61, p32-41.

[12] Cheshire, P. \& Hilber, C. (2020). What will Crashing the Economy do for the UK Housing Market?. LSE COVID-19 Blog, 25th of May, mimeo

[13] Del Giudice, V., De Paola, P., \&Del Guidice, F.P. (2020). COVID-19 Infects Real Estate Markets: Short and Mid-Run Effects on Housing Prices in Campania Region (Italy). Social Science MDPI, Open Access Journal, 9(7), 1-18.

[14] El Montasser, G., Fry, J. \& Apregis, N. (2016), "Explosive Bubbles in the US-China Exchange Rate: Evidence from the Right-tailed Unit Root Tests", China Economic Journal, 9(1), pp. 34-46, Taylor\&Francis.

[15] Evans, G. (1991). Pitfalls in Testing for Explosive Bubbles in Asset Prices. The American Economic Review, 81(4), 922-930. 
[16] Ghiaie, H. (2020). Housing, the Credit Market and Unconventional Monetary Policies: From the Sovereign Crisis to the Great Lockdown. ESCP Business School, mimeo, October 18th; Available at SSRN:

[17] Gigglio, S., Maggiori, M., \& Stroebel, J. (2014). No-Bubble Condition: Model-Free Tests in Housing Markets. NBER Working Paper \#20154, Cambridge, MA, May. Doi: 10.3386/w20154

[18] Gleaser, E. (2017). Real Estate Bubbles and Urban Development. Asian Development Review, 34(2), 114-151.

[19] Gleaser, E., \&Nathanson, C. (2014). Housing Bubbles. NBER Working Paper \#20426, Cambridge, MA, August. Doi: 10.3386/w20426

[20] Hoesli, M., \&Malle, R., Commercial Real Estate Prices and Covid-19 (2021), Swiss Finance Institute Research Paper No. 21-08, Available at SSRN

[21] Homm, U., \& Breitung, J. (2012). Testing for Speculative Bubbles in Stock Markets: A Comparison of Alternative Methods. Journal of Financial Econometrics, 10(1), 198-231.

[22] Hu, M., Lee, A. D. \&Zou, D.(2021), COVID-19 and Housing Prices: Australian Evidence with Daily Hedonic Returns. Available at SSRN

[23] Huang, N., Pang, J. \&Yang, Y. (2020), The Impact of the COVID-19 Epidemic on the Housing Market in China. Mimeo, July $3^{\text {rd }}$; Available at SSRN

[24] Jorda, O., Schularick, M., \&Taylor, A. (2015). Leveraged Bubbles. NBER Working Paper \#21486, Cambridge, MA, August. Doi: 10.3386/w21486

[25] Kansu, A. (2011). Konut balonundan finansal krize ABD mortgage krizi. Ýstanbul: Scala Press.

[26] Karpook, D., Stillebroer, D.,.\&Jaspers, E. (2020), New Demands for Resilience in Real Estate : Resilience and Adaptability after the COVID-19 Pandemic. Corporate Real Estate Journal, Volume 10 Number 1, Autumn/Fall 2020, 106-116 (11)

[27] Kholodilin, K., \& Michelsen, C. (2018). Signs of New Housing Bubble in many OECD Countries: Lower risk in Germany. DIW Weekly Report, ISSN 2568-7697, 8(30/31), 275-285. Deutsches Institut für Wirtschaftsforschung (DIW), Berlin

[28] Liu, F., Liu, D., Malekian, R., Li, Z., \&Wang, D. (2017). A Measurement Model for Real Estate Bubble Size based on the Panel Data Analysis: An Empirical Case Study. PLoS ONE 12(3): e0173287.

[29] Liu, S. \&Su, Y. (2020). The Impact of the COVID-19 Pandemic on the Demand for Density: Evidence from the U.S. Housing Market. , 47 pages, August 19th

[30] Maimbo, S. M., \& Ratha, D. (Eds.). (2005). Remittances: Development impact and future prospects. Washington, DC: The World Bank.

[31] Mishra, S. (2021). Impact of Coronavirus on Indian Real Estate. Housing.com, January 29th, mimeo

[32] Bank for International Settlements (2020), National sources, BIS Residential Property Price database. Retrived from http://www.bis.org/statistics/pp.htm (First accessed on 10 April 2020).

[33] Nicola M., Alsafi, Z., Sohrabi, C., Kerwan, A., Al-Jabir, A., Iosifidis, C., Agha, M., \& Agha, R. (2020). The Socio-Economic Implications of the Coronavirus Pandemic (COVID-19): A Review", International Journal of surgery, 78, 185-193.

[34] Nuredini, B. (2020), Impact of the COVID-19 Pandemic on the Global Real Estate Market, Geo-SEE Institute Working Paper No. 15, UDC:616.98:578.834-036.21:[334.124.4(100)"2020", mimeo.

[35] OECD (2020), Housing prices (indicator). Retrived from doi: 10.1787/63008438-en (First accessed on 10 April 2020)

[36] Phillips P., Wu, Y., \&Yu, J. (2011). Explosive Behavior in the 1990s NASDAQ: When Did Exuberance Escalate Asset Values?. International Economic Review, 52(1), 201-226.

[37] Phillips, P., Shi, S., \&Yu, J. (2015). Testing for Multiple Bubbles: Historical Episodes of Exuberance and Collapse in the S\&P 500. International Economic Review, 56(4), 1043-1078.

[38] Schnure, C. (2020). How Has the Lockdown Impacted Commercial Real Estate Sales and Prices?. Nareit - Real Estate working for You. June $7^{\text {th }}$, mimeo

Received: 2021-01-31

Revision requested: 2021-02-04

Revised: 2021-05-07 (3 revisions)

Accepted: 2021-05-11 


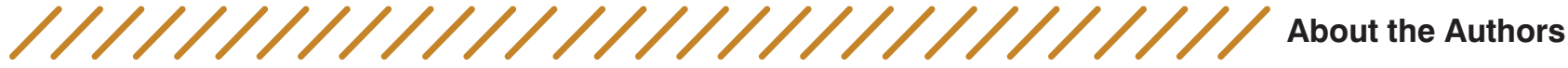

\section{Marko Malović \\ Educons University, 21208 Novi Sad, Serbia profmarkomalovic@gmail.com}

Prof. Marko Malović, PhD, is a Full Professor and Dean of the Faculty of Business Economics at Educons University, Novi Sad, Serbia. His areas of research and academic interest are International Finance, Open Economy Macro, Economics of European Integration and Global Banking. Marko Malovic is a Member of Euromoney's Expert Panel of Economists on Country Risk and Sovereign Debt Repayment Capacity.

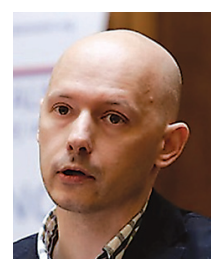

Miloš Roganović

Faculty of Business, Economics and Entrepreneurship, 11000 Belgrade, Serbia milos.roganovic@vspep.edu.rs

Miloš Roganović is a Teaching Assistant at the Faculty of Business Economics and Entrepreneurship, Belgrade, Serbia and a PhD candidate at the Faculty of Business Economics, Educons University, Novi Sad, Serbia. His areas of research are International Finance, Financial Crises, Monetary Policy. He was a participant in the international project New Business Tendencies funded by the Faculty of Business Economics and Entrepreneurship, Belgrade, Serbia.

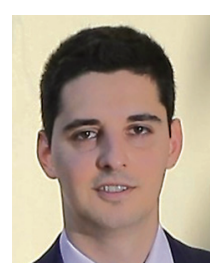

\section{Mustafa Özer \\ Anadolu University, Eskişehir, Turkey muozer@anadolu.edu.tr}

Prof. Mustafa Özer, PhD, is an economist who lectures at the Anadolu University, Eskişehir, Turkey in the capacity of Full Professor. His areas of research are Applied Econometrics, Financial Crises, Business Cycles, as well as Civil Society. He has been the director of research project of 'The Role of Civil Society in Turkey' sponsored by Johns Hopkins University of the USA and the Anadolu University of Turkey. Further, Mustafa Özer is a member of the editorial board of the Journal of Risk Management, and various journals in Turkey. Mustafa Özer is also a member of the scientific committee of MIBES and EconAnadolu.

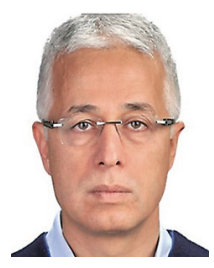

